\title{
Composition, uses, provenance and stability of rocks and ancient mortars in a Theban Tomb of Luxor (Egypt)
}

Cuezva, S.(1); Garcia-Guinea, J.(1*); Fernandez-Cortes, A.(1); Benavente, D.(2); Ivars, J.(3); Galan, J.M.(3), Sanchez-Moral, S.(1).

(1) Museo Nacional de Ciencias Naturales (CSIC). C/José Gutiérrez Abascal 2, Madrid, 28006, Spain.

(2) Universidad de Alicante. Ctra. San Vicente del Raspeig s/n, Alicante, 03690, Spain.

(3) Centro de Ciencias Humanas y Sociales (CSIC). C/Albasanz 26-28, Madrid, 28037, Spain.

$\left(^{\star}\right)$ Author for correspondence: guinea@mncn.csic.es; Phone +0034 914111328

\begin{abstract}
The rock-cut tomb-chapel of Djehuty (Luxor, Egypt, 1470 B.C.) was excavated and restored including a mineralogical, chemical, textural and petrophysical study of mortars and host rocks together with micro-environmental parameter recordings to infer on the techniques used by the ancient Egyptian builders. The host rock is made by alternations of massive, nodular and finely bedded micritic limestone and the tomb was excavated in the stratigraphic section with better mechanical properties. Different types of gypsum and lime mortars were found in the funerary complex: mortar for bedding, exterior render, surface repair and decoration, and interior plaster and coating. Mortars show formulae according to their specific applications and locations. The sources of the mortar raw materials reveal a local provenance. Micro-environmental conditions play an important role in the evolution of the mortar pastes, and determine the current characteristics and stability of mortars. Results from this research will permit to design mortars compatible with conservation in the funerary complex of Djehuty and to define safe micro-environmental conditions for the preservation of such mortars and paintings.
\end{abstract}

Keywords: Ancient Egyptian material; mortar; micro-environment; Theban tomb; gypsum; anhydrite.

\section{Introduction}

The degradation of building materials of architectural heritage is of much interest among scientists since new restoration materials frequently fail to guarantee compatibility with the ancient masonry and weathered surfaces [1-2]. The investigation on composition, physical properties, uses, production and provenance of ancient construction materials including rocks substrata is of great significance in achieving future effective conservation of ancient 
monuments [3, and citations therein]. Moreover, the study of microclimate conditions and environmental monitoring has emerged as an essential research for the conservation and restoration of monuments [4]. The constrained published studies on Egyptian stones, mortars, plasters and stuccoes, i.e., ancient-originals, historical-restorations and suitable restoration mortars provide crucial information to keep this valuable Cultural Heritage and the future wealth of the associated tourist activity. The publications to date concern the porous structure and composition of mortars [5-9], the geo-mechanics of stones and mortars [10-12] and soluble salts deteriorating Pharaonic and Coptic wall paintings [13-14]. Besides, the long-term monitoring of the microclimatic and environmental factors of the sites has proved are one of the key issues addressing the preservation and management of these ancient Egyptian monuments, particularly to evaluate and manage the effects of visitors on the conditions of the tombs [15].

The characterization of the physical-mechanical, microstructural and chemical properties of both host rock and ancient mortars is a crucial setting criterion for choosing suitable repair mortars to preserve the integrity and authenticity of ancient structures [16-17]. In this regard, RILEM (The International Union of Laboratories and Experts in Construction Materials, Systems and Structures) publications provide useful recommendations to classify functions and nature of mortar's binder and aggregates and on the most appropriate methods and techniques for their study [18-20]. For the preparation of ancient mortars and concretes various materials were employed such as gypsum limes used for rendering, but carbonated limes were dominantly used in structural mortars [21].

The rock and mortars' study started in 2002 within a long-term Spanish archaeological mission working on the West Bank of Luxor to excavate and restore the rock-cut tomb-chapel of Djehuty (TT 11) at the foothill slope of Dra Abu el-Naga, ca. 1470 BC [22-23]. The tomb-chapel was decorated in relief and hewn in a carbonate sedimentary sequence with diverse properties belonging to the well-known Thebes' geological formation [24-25]. The complex monument contains different types of mortars used along different building roles. The aim of this paper is to characterize host rocks of the tomb-chapel together with ancient Egyptian mortars classifying their functions and nature of binder and aggregates following the RILEM recommendations [18-20]. Nearly fifty microsamples of mortars and rocks were analyzed by environmental scanning electron microscopy (ESEM) with an attached X-ray energy dispersive system (EDS) and spectral cathodoluminescence detector (CL), X-ray diffraction (XRD), $X$-ray spectrometry analysis (XRF) and mercury intrusion porosimetry (MIP). The external meteorological conditions of the archaeological site and the microenvironment conditions within Djehuty's tomb-chapel were simultaneously recorded. 


\section{Site, materials and methods}

\subsection{The rock-cut tomb-chapel of Djehuty (TT11).}

The studied rock-cut tomb-chapel of Djehuty (TT 11) is dated to the early XVIII ${ }^{\text {th }}$ Dynasty, ca. 1470 BC [22]. It is located in the central area of Dra Abu el-Naga, at the northern end of the Theban necropolis (Luxor, Egypt) (Fig. 1). The monument has an open courtyard $34 \mathrm{~m}$ long and width that varies between $7.60 \mathrm{~m}$ (tomb-chapel façade) to $6.30 \mathrm{~m}$ (court entrance) (Figs. 1 and 2). The side-walls are carved in rock being extended by a mud-brick (adobe) wall on the West side and by masonry surmounted by layers of mud-bricks on the East wall, up to reach a height of at least $2.91 \mathrm{~m}$. There are remains of the mortar that covered the side-walls, both, on the hill rock and on the mud-bricks. The tomb of Djehuty originally had an open and roofless hall (closed and covered by the Department of Antiquities of Egypt since sixties), with inscriptions on both sides of the original door of the tomb and sculpture of Djehuty which are carved on its North and East walls respectively. The sculpture of Djehuty was framed into a white box of hard lime mortar. The tomb-chapel mainly consists of two levels. The upper level of the tomb-chapel, the funerary chapel, has inverted T-shaped. The inner part penetrates horizontally $18 \mathrm{~m}$ inside the rock of the hill. First a transverse corridor has relief decoration showing a variety of different scenes and inscriptions carved on its walls. Then a narrow central corridor leading to the innermost room of the chapel is also decorated with reliefs. The innermost room (shrine) is decorated in high quality raised relief displaying the most significant moments of Djehuty's ideal funerary rituals. The right side is entirely occupied by a funerary shaft which descends vertically $8.15 \mathrm{~m}$ to a broad chamber. At the rear end there is a second shaft, $3 \mathrm{~m}$ deep. At the southern shorter side there is an entrance to a second chamber measuring 3.65 $\mathrm{m} \times 3.50 \mathrm{~m} \times 1.55 \mathrm{~m}$. This is the burial chamber where west and north walls as well as an area of the ceiling remained coated with mortars on which passages from one of the earliest Book of the Dead are written [23].

\subsection{Geological frame of the rock-cut tomb-chapel of Djehuty (TT11).}

The tomb-chapel was hewn into a carbonated sedimentary sequence of Eocene age (Ypresian, 55.8-48.6 M.y.), in particular in the lower member (Member I) of the Thebes Formation (Fig. 1). The type-section of this Formation is located at Gebel El-Qurn [24] next to the tombs area, and the stratigraphic sequence was described in detail by Tawfik et al [25]. Moreover, this geological formation has been extensively studied for its archaeological significance, mainly in the Valley of Kings, e.g., references [26-27]. The local stratigraphic sequence consists of circa $38 \mathrm{~m}$ of beds of variable thickness from few centimetres to several metres mainly composed by massive or nodular limestone rocks. A subdivision into 5 sub-beds or sections based on field observations was performed and sampled (Fig. 2). 


\subsection{Climatic and microenvironment monitoring.}

A monitoring programme was launched in 2008 and it is still working at the archaeological site. Three HOBO Pro v2 data-loggers (Onset Computer Corporation, Bourne, MA, USA) with built-in temperature (accuracy \pm 0.2 over $0^{\circ}-50{ }^{\circ} \mathrm{C}$, resolution 0.02 at $25{ }^{\circ} \mathrm{C}$ ) and relative humidity $\mathrm{RH}$ (range $0-100 \%$, accuracy $\pm 2.5 \%$ from $10-90 \%$, resolution $0.03 \%$ ) sensors were installed to record these air parameters to the hour o'clock, at three locations: (i) exterior (courtyard), (ii) shrine and (iii) burial chamber.

Also meteorological data of the study area were analysed by using the surface weather conditions of Luxor city from the last 30 years. Data are available at the USAF DATSAV3 Surface Observations data base managed by the NOAA's National Climatic Data Center [28]. The USAF Luxor station number 624050 $\left(25^{\circ} 40^{\prime} 1.2^{\prime \prime} \mathrm{N}, 32^{\circ} 42^{\prime} 00^{\prime \prime} \mathrm{W}, 87 \mathrm{~m}\right.$ a.s.l) is located in Luxor airport $10.5 \mathrm{~km}$ away from Djehuty's tomb-chapel (25044'11.07'N, 32037'24.61"E, $101 \mathrm{~m}$ a.s.l).

\subsection{Micro-samples collection and analytical methods.}

Prior to the micro-invasive sampling, detailed and comprehensive in-situ visual analyses were performed together with the necessary understanding of the monument complexity, as RILEM indicates [19].

A total of 36 mortar micro-samples were carefully collected during the archaeological works conducted from 2006 to 2010 to be analyzed by XRD, XRF, ESEM-EDS, CL and MIP depending of the specific minimum sample size. The main mortars sampling criteria were uses or functions in accordance with the RILEM association classifications [18-20]. Samplings were performed by setting mortar location (i.e., outside, inside, distance to the water table) and mortar colors and textures (Table 1). A second samples collection target was the local geological stratigraphic column to obtain correlation materials to be compared with local mortars for provenance studies (Fig. 2).

Qualitative, quantitative and micro-textural XRD analyses of powdered Egyptian mortar and rock samples were performed using XPOWDER software which allows a full duplex control of the Philips PW-1710/00 diffractometer using the CuKa radiation from 5 to $65^{\circ} \otimes$ with a $\mathrm{Ni}$ filter and a setting of $40 \mathrm{kV}$ and 40mA.The chemical XRF analyses were performed in a Magic Philips X-ray fluorescence spectrometer operating an ultra-thin window and rhodium anode $\mathrm{X}$-ray tube at $2.4 \mathrm{~kW}$. The quantitative determinations were performed by both the IQ+ software of Panalytical-Philips and by calibration curve with mineral standards. The environmental electron microscopy studies were performed under a FEI Inspect ESEM microscope. The ESEM resolution at low-vacuum recording the backscattering images was at $4.0 \mathrm{~nm}$ at $30 \mathrm{kVSpot}$ samples of EDS analyses and mapping areas were carried out with an energy dispersive $X-$ ray spectrometer, Oxford Instruments INCA Energy 200 Energy Dispersive 
System. The ESEM microscope has a coupled MONOCL3 Gatan probe to allow the cathodoluminescence spectra recording. Connected porosity and pore size distribution were obtained from MIP with an Autopore IV 9500 Micrometrics mercury porosimeter. The pore size interval characterization by MIP ranged in a radius range of $0.003-200 \mu \mathrm{m}$ which corresponds respectively to highest and lowest head pressures. The determination of the specific surface area (SSA) was carried out through the BET method in the relative pressure interval $P / P_{0}=$ 0.05-0.2 using an Autosorb-6 Quantachrome apparatus. Micro-compression characterization was performed in samples sized $10 \times 10 \times 10 \mathrm{~mm}$ using a uniaxial compression press (Instron 4411) with a maximum load of $5000 \mathrm{kN}$ and a constant load velocity of $0.1 \mathrm{MPa} / \mathrm{s}$. The specimen size was consistent with the standard mechanical tests, which recommend that specimen size should be at least ten times larger than grain size [10].

\section{Results}

\subsection{Climatic and microenvironment conditions}

The Luxor climate is strongly arid being classified as hyper-desert and extreme Mediterranean type. During last 30 years the annual mean temperature of air was $25.1^{\circ} \mathrm{C}$, with a maximum inter-annual variation below $1.6^{\circ} \mathrm{C}$. The absolute maximum of air temperature for each annual cycle has always been above 45 ${ }^{\circ} \mathrm{C}$ and minima reached $1.4^{\circ} \mathrm{C}$ on average with very rare frost events. Rainfall has been almost anecdotal in the last three decades, so just a total amount of $470 \mathrm{~mm}$ has been registered since 1980 with a $43 \%$ of years with total absence of rainfall events. The rain episodes are focused in few days ( 3 days per year on average) and some of them correspond to torrential events. The dry conditions and extreme temperatures determine a very low $\mathrm{RH}$ of air $(37.8 \%$ on average) ranging from 32.5 to $40.3 \%$ in terms of annual average.

The environmental monitoring (2008-2011 period) provided measurements on temperature and $\mathrm{RH}$ of outdoor air (open courtyard), being warmer and drier $\left(31.5^{\circ} \mathrm{C}\right.$ and $\sim 19.5 \%$, respectively, on annual average) than those registered in Luxor city. Moreover, these extreme environmental conditions are softened by the neighbouring Nile riverbed. The annual mean temperature of air at Djehuty's innermost room (shrine) drops to $29.5^{\circ} \mathrm{C}$ and $\mathrm{RH}$ rises up to $22.1 \%$. When the funerary shaft, $8.20 \mathrm{~m}$ deep, was excavated (February 2008), the antechamber was reached and opened. The air temperature and $\mathrm{RH}$ remained around $28^{\circ} \mathrm{C}$ and slightly above $80 \%$, respectively. These environmental ranges could be close to those under pristine conditions before any modern archaeological excavation. Similar environmental conditions were registered later at the bottom of another funerary shaft excavated during 2010 (28.5 ${ }^{\circ} \mathrm{C}$ and $\left.78.2 \%\right)$, which reaches a similar depth than the burial chamber of Djehuty. The higher values 
of $\mathrm{RH}$ with depth are related to the proximity of the Nile water table, located from 2.5 to 2 meters below the burial chamber.

\subsection{Mineralogical, chemical and petrophysical characteristics of host rock.}

The host rock in which the rock-cut tomb is located consists of alternations of massive, nodular and thinly bedded micritic limestone. The tomb was excavated into four of the five local stratigraphic sections according to field observations (Fig. 2). These sections are described below, with special attention to their mineralogical, chemical and petrophysical characteristics.

Section 1 (S1) is composed by massive white-pale-brown limestone beds with few centimetre thicknesses (Fig. 2). It is the section in which the burial chamber of the tomb was excavated. This limestone is fine grained and quite porous being predominantly composed by remains of calcareous nano-plankton (mainly coccolithophores, Fig. 5a) and micro-plankton (mainly foraminifers) with abundant fragments of mollusc shells. It shows vertical fissures filled with gypsum and calcite. The XRD analysis (Table 2) show a dominantly calcite mineral composition (85-90\%). The XRF analyses display a chemical composition in good agreement with the mineralogical composition being only noticeable a sample with an important amount of $\mathrm{Th}, \mathrm{Ba}$ and $\mathrm{Cl}$ elements and other with some Cs.

Section 2 (S2) exhibits white-pale-brown massive limestone inter-bedded with limestone sheet-beds. Near to the section top, the bed thickness of nodule limestone increases in comparison with massive beds (Fig. 2). The XRD analysis shows a not so dominant presence of calcite (75-80\%) (Table 2). The XRF analyses display a chemical composition with more $\mathrm{Fe}, \mathrm{Mg}, \mathrm{Cr}$ and $\mathrm{Ce}$.

Section 3 (S3) is composed by inter-bedded strata of pink to white-pale-brown massive and nodule limestone with slightly dolomitized levels. Near the section top, the massive beds thickness increases in comparison with nodule limestone beds (Fig. 2). Section 3 shows the higher proportion of phyllosilicate minerals (Table 2). The XRF analyses display a chemical composition with more Fe, Al, $\mathrm{Mg}, \mathrm{Sr}$ and $\mathrm{Mn}$. It is also noticeable some higher amounts of $\mathrm{S}, \mathrm{Cs}, \mathrm{Th}, \mathrm{Cr}, \mathrm{Ba}$ and Ce.

Section 4 (S4) in which the upper level of the tomb-chapel is located, is pink massive limestone (Fig. 2). The mineral composition is again predominantly calcite (Table 2). The XRF analyses display a chemical composition in agreement with the mineralogical composition.

Petrophysical properties of the host rocks are strongly influenced by their mineralogical and textural characteristics (Table 2). Porosity is mainly interparticle, increasing from the geological rock cementation decrease from S1 to S4. Porosity values are therefore lower in the bottom of the geological column (S1-S2) than in the top (S3-S4). Some thin fissures and veins are also founded 
and randomly distributed. Pore size distribution of the inter-particle porosity highlights the lithological variation through the geological column (Fig. 3). In S1, host rock is more fine-grained and tent to be less cemented at the top, so that pore size increase from the S1 to S4. The pick height also rises since it reflects the increment of the pore volume or porosity value (Table 2). Pore size displays two pore modes. The most important and abundant has large size values being related to the inter-granular porosity -pore space between bioclasts and/or terrigenous grains. The second pore family presents less pore volume; it is placed at lower pore size values and is formed by micritic calcite and/or clay minerals.

Clay minerals have special importance in both the specific surface area (SSA) and mechanical strength. Host rock in geological S1 and S3 contains phyllosilicates (mainly illite) and also comprises the largest SSA values and lowest compressive strength values (Table 2). The presence of clay minerals increase the surface area of host rock since present both a small size (external surface area related to large area/volume ratio) and micro-porosity (inner surface area), which explain SSA values slightly higher in S1 and S3 than in S2 and S4. The inter-particle clay minerals are usually found in the rock cement, binding the grains together. This type of binding phase decreases the mechanical strength and also increases their susceptibility to deterioration. So the presence of clay minerals produces rock softening [29] and clay-bearing host rock presents less values of compressive strength (S1 and S3). The studied rocks presented a low compressive strength (13-31 MPa). Microcharacterization provides mechanical values in the same range as mesocharacterisation of similar kinds of rocks [30]. Moreover, the stress-strain analyses performed in some micro host rocks samples reveals a stress-strain behaviour relatively linear and brittle fracture [10].

\subsection{Types of mortar on the funerary complex of Djehuty by visual analysis.}

The in-situ visual analysis of the monument allowed us to recognize the main building elements and to discriminate different types of mortar according to their specific applications [19] (Table 1).

(1) Bedding mortar or mortar joint is a mortar for setting masonry units (mudbricks), for adhesion and bearing load, according to the functional categories defined by the RILEM [20]. It corresponds to the type 4, Masonry mortars: (i) bedding, defined in the previous RILEM classification [18]. It is located outside the tomb-chapel, and it was used to bind mud-brick and rock units of the open courtyard masonry walls (Fig. 4a). A total of 15 microsamples collected at different locations were studied. 
(2) Mortar for exterior render. That exterior render group are mortar coatings and stuccoes applied to the external surfaces (Fig. 4b), for water penetration protection and aesthetic covering [20]. It is layer structured as follows: a first mortar-coating layer, for flattening the rock/mud-brick substrate, when required; a second mortar-coating layer, for smoothing; and last an aesthetic layer of stucco. In some cases, only the second layer is present. This mortar corresponds to the type 2, Mortars for the application of facings: (ii) walls of the previous RILEM classification [18]. It is located outside the tomb-chapel, covering open courtyard masonry (mud-brick and stone blocks) and rock-carved walls. A total of 15 such micro-samples type collected at different locations were studied.

(3) Mortar for surface repair is the mortar employed to replace and repair missing sections of masonry [20]. It corresponds to the type 5(v) Special mortars for repairs, defined in the previous RILEM classification [18]. It is a mortar for clamping and replacement of fallen rock. It is used for the replacement of rock fall during the excavation of the tomb and the filling of gaps (Fig. 4c and Fig. 4d, sample M23). It is applied in direct contact with the rock and sometimes includes rock fragments. It is located both inside and outside of the tomb-chapel. A total of 9 micro-samples was studied, 3 located outside and 6 located inside the tomb-chapel.

(4) Interior plaster and coating is an aesthetic covering, a substrate for decoration [20], employed inside. It is equivalent to the 1, Mortar for plaster, defined in the previous RILEM classification of mortars [18]. It is located inside the tomb-chapel, in the burial chamber, and it is applied to walls and ceiling (Fig. 4e). It is layer structured as follows: first, a leveler layer of mortar is applied directly on the lowered and smoothen rock wall / ceiling. This layer is covered by a plaster layer, eventually painted. 3 micro-samples were studied.

(5) Mortar for decoration. This type was not included in the last RILEM classification [20], but corresponds to the 3.Mortars for decoration: (i) layered, (ii) relief, defined in the previous RILEM classification [18]. In this group we include the thin mortar layer surrounding the statue of Djehuty, located in the Hall of the Open Courtyard (Fig. 4d).

\subsection{Mineralogical, chemical, textural and petrophysical characteristics of mortars.}

The mineralogical, chemical, textural and petrophysical characteristics of the studied mortars have shown variability mainly related to their specific use and location. 
Bedding mortars exhibit variable mineral compositions, with a predominance of calcite as a main mineral component in most samples (Table 3). Average values for these carbonated bedding mortars are calcite $56 \%$, quartz $17 \%$, illite $10 \%$, feldspar $7 \%$, dolomite $4 \%$ anhydrite $3 \%$ gypsum $1 \%$ and sepiolite $1 \%$. Also there is a second type of bedding mortars, whose main component is calcium sulphate (anhydrite) that appears as another constructive phase. Average values for these calcium sulphate bedding mortars: anhydrite $45 \%$, calcite $32 \%$, quartz $9 \%$, illite $4 \%$, sepiolite $4 \%$, feldspar $3 \%$ and dolomite $3 \%$. A third type of bedding mortars whose main component is carbonated mud, appears represented by two samples. The average mineralogical composition of these carbonated mud bedding mortars is calcite $25 \%$, quartz $23 \%$, illite $17 \%$, feldspar $14 \%$, dolomite $2 \%$ and sepiolite $18 \%$.

Mortars for exterior render exhibit variable mineral compositions related to its structural position (Table 3). The first mortar-coating layer (carbonate-mud render), in direct contact with the host rock or mud-bricks, is a mixture of limestone and straw fragments with an average mineral composition of calcite $43 \%$, quartz $20 \%$, illite $19 \%$, feldspar $12 \%$, sepiolite $5 \%$ and dolomite $2 \%$. The second mortar-coating layer (carbonated render), more fine-grained, is mainly composed by a $85-95 \%$ of calcite with minor amounts of quartz and dolomite (3.4 and $2 \%$ average values respectively) and occasionally accessorial traces of sepiolite, illite and anhydrite are also detected. Exceptionally gypsum is present as an accessory component in two samples taken from the wall of the outer courtyard, M21 as bedding mortar and M13 as external render. These samples are collected in an area of the wall that was covered by sediments but was exposed after the excavation. The chemical compositions of these mortars (Table 4) are notable for the high proportion of $\mathrm{F}, \mathrm{Cl}$ and $\mathrm{Br}$. The ratio $\mathrm{Cl} / \mathrm{Br} \sim 10$ is much lower than in the other sample, which reaches values above 200. The last aesthetic render layer (stucco render), is mainly composed by $83-99 \%$ of anhydrite with minor amounts of calcite (0.5-2.5\%) and occasionally traces of quartz, illite and gypsum. These samples exhibit white color with grey hues in samples with more accessorial aggregate grains, i.e., quartz, feldspar, etc. In $\mathrm{XRF}, \mathrm{Sr}$ is very high in these mortars with $\mathrm{CaSO}_{4}$ as binder.

Mortars for surface repair show a mineral composition quite homogeneous mainly composed by a $70-95 \%$ of anhydrite, with accessorial quartz (1.5-16\%), calcite (0.5-11\%) and feldspar (0-7\%). It is located both inside and outside of the tomb-chapel and the presence of gypsum (3-9\%) was only detected in the samples from the innermost rooms (central corridor and shrine). The chemical compositions of these mortars are notable for the high proportion of Sr.

Interior plasters and coating from burial chamber also exhibit variable mineral compositions according to its structural position. The first mortar-coating is mainly composed by gypsum (48\%) and calcite (33\%), with accessorial quartz (17\%). In contrast, the final aesthetic plaster layer consists mainly of gypsum (around 80\%) and accessorial quartz, in the absence of calcite. Also presence 
of $10 \%$ anhydrite was detected in sample M30 (Table 3 ). It is also worth to indicate the mineralogical analysis of two samples (M32-33) of mortar under preparation found in a bowl on the burial chamber having great similarity to those of the first-mortar coating, gypsum 50\%, calcite $32 \%$ and quartz $18 \%$.

Mortar for decoration represented by the micro-sample M24 it was collected from the white wall of Djehuty's statue niche adjoining the façade (Fig. 4d), displaying a different mineralogical approximated composition, as follows: anhydrite $13 \%$, calcite $68 \%$, huntite $15 \%$, quartz $2 \%$ and dolomite $2 \%$. It is an interesting white and hard mortar sample including huntite as bleaching agent and disposed as background of Djehuty's statue.

The ESEM confirmed mineralogical and chemical analyses performed along with different categories of mortars (Fig. 5). The ESEM provided frequent images of coccolithophore fragments in carbonated mortars (Fig $5 b$ and $5 c$ ), and different calcium phosphate morphologies in the mortar aggregates (Fig. $5 d$ and $5 \mathrm{e}$ ). The backscattering probe highlights heavy elements such as zircon or REE in minerals. The cathodoluminescence probe provides spectral features of apatite grains containing REE and luminescence plots outlining their distribution. EDS analyses of zircon and monazite grains show carbon and calcium analysed into the host matrix. The monazite EDS spot analysis shows La 11.42; Ce 21.68; Nd 6.20 and $\operatorname{Pr} 1.11 \%$ in agreement with a monazite-(Ce) standard formula (Ce,La,Nd,Th) $\mathrm{PO}_{4}$ in our case, without Th and with $\mathrm{Pr}$ and $\mathrm{Sm}$ in similar proportions recalculating without the surrounding host calcium. We performed spectra CL from the monazite surface and several Ca-phosphate grains to observe the entrance of different proportions of REE elements in structural positions of $\mathrm{Ca}^{2+}$ producing characteristic narrow $\mathrm{CL}$ peaks associated to REE following the cathodoluminescence defect-emission attributions of Blanch [31].

Pore structure of the studied mortars also depends mainly on their use/application and mineralogical composition. All the studied mortars present very high values of porosity in which calcium sulphate mortars have higher porosity values than in calcite mortars (Table 5). Porosity values in masonry mortars for surface repair (50-62\%) and calcium sulphate exterior renders (58$68 \%)$ are higher than bedding mortars (31\%) and carbonated mortars for exterior render (43-48\%). The pore size distribution (PSD) is poorly sorted or poly-modal, the number and volume of pore modes is defined by the binder and aggregates relationships (Fig. 6). PSD of mortars contrast with host rocks ones, which has a narrow size range. The PSD pattern is very complex, although some general tendencies can be appreciated. Calcium sulphate mortars present a mode size around $1 \mu \mathrm{m}$ (e.g. M4, M15) whereas carbonatic mortars present a wide mode size in the $0.1-1 \mu \mathrm{m}$ ranges (e.g. M6, M11). In sort, the amount and kind of aggregates decrease sorting. 
Specific surface area values (SSA) of the studied mortars range from $1-18 \mathrm{~m}^{2} / \mathrm{g}$ (Table 5). SSA values for mortars are similar than the host rock $\left(3-6 \mathrm{~m}^{2} / \mathrm{g}\right)$ although they present a different PSD. The fraction of thin pores and the high porosity values for mortars explains these values. The presence of clay minerals as aggregates supply values of SSA higher than the rest of the studied mortars and have special significance in M11, M14 and M21.

The characterisation of mechanical strength has been only carried out for the calcium sulphate exterior render mortars $\mathrm{M} 9, \mathrm{M} 10$ and $\mathrm{M} 11$ due to sample size limitation. The studied mortars presented a very low compressive strength (0.25-1.60 MPa). References to the mechanical strength of ancient mortars are scarce in the literature since their determination requires large samples. Hence, we compared our results to those for repairing mortars with similar properties to the studied ancient mortars. The values obtained from micro-compressive analyses are comparable to meso-compressive values for repairing mortars $[10,30]$.

\section{Discussion}

4.1. Host rock features and construction and conservation/stability of the tombchapel.

The host rock exhibit low mechanical strength (Table 2), stress-strain behavior relatively linear and brittle fracture $[10,30]$. The presence of a dense network of fissures intensifies its low mechanical strength favoring an anisotropic mechanical behavior and causing fractures, blocks dropping and subsequent collapses. The hewing of the tomb-chapel itself caused severe mechanical stress in the rock being confirmed by numerous boulders fallen during the carving process, later repositioned by fixing mortars (Fig. 4c). This fact is more severe in the softer rocks of the geological sections. Compressive strength values in geological S1 and S3 are lower than in S2 and S4.

Djehuty built his tomb-chapel at the foothill of Dra Abu el-Naga, at ground level, where the limestone has the better mechanical properties of the geological column (S4). The host rock at this level is massive and stable enough to allow relief carving and then covering the surface with a very thin whitewash layer upon which the pigments could be applied. Even now some of the walls of the tomb exhibit a relatively good state of conservation and some painting remains. As in the case of the upper level of the tomb-chapel, the burial chamber was hewn into a massive limestone level (S1) but with poorer mechanical properties (Table 2). Probably, these properties were considered when it decided not to decorate it in relief, but at this level it was advisable to use mortars, preparation layers and finally the pigments. Moreover, in this geological section salt weathering is commonly linked to capillary waters. The burial chamber reaches 
down $12 \mathrm{~m}$ below ground level, a few meters above the Nile water table. The water table undergoes significant seasonal oscillations and still today there is a variation between summer and winter associated with dam gates opening and closing. PSD curves of host rocks are well sorted and show a pore mode in the size interval of 0.04-0.2 $\mu \mathrm{m}$ (Fig. 3). Capillary water transport is active in this pore range and the capillary forces are important [29]. This movement, although slow, periodically transports water with ions to the burial chamber's walls and after dry seasons, salt precipitation is then observed. The host rock is susceptible to be weathered by salt crystallization. It presents significant values of connected porosity and small pore size (circa $0.1 \mu \mathrm{m}$ ) which favors the effectiveness of salt stress, and low mechanical strength, which is considered the material's resistance to the mechanical action of salt crystallization.

Gypsum and halite salts are frequently observed onto surfaces particularly on the lower half of the burial chamber's walls and inside cracks of the host rock in S1 (Fig. 3). Hence, rock deterioration by salt weathering is not really significant because the crystallization pressures of gypsum and halite are relatively harmless [32-33] and the air remains constant most of the time. Salt deterioration takes place by repeated crystallization-dissolution process prompted by variations in the relative humidity and temperature [32]. As a result, the stable and dry microclimatic conditions of Djehuty's tomb-chapel reduce the salt deterioration in the porous materials and salts tend to grow as efflorescence (mainly gypsum and halite), causing aesthetic and surface physical damage. Gypsum and halite salts are also found onto mortar surfaces. Limestone bedrock salts migrate to the rock-mortar interface and precipitate detaching mortar plates from the rock.

\subsection{Provenance and stability of the mortars.}

The application of a proper combination of analytical techniques [19] on mortars has shown obvious relationships between intrinsic properties and its specific use in the tomb-chapel of Djehuty. Such bedding mortars of the external masonry are the least porous ( $30 \%)$ which provides the best mechanical properties to be used as structural mortars. The suitable ratio of clay and quartz in the exterior renders ensures adequate strength and flexibility properties for these mortars. Clay acts as binder and plastic medium to glue together with the other ingredients. The sand grains ensure the stretch when dry. The inclusion of straw reduces cracking, ensures the strength and also the speed in drying. The presence of calcite improves the mechanical resistance and stability. The final calcium-sulphate stucco renders not only improve the appearance of the exterior walls, but also helps to protect it against weathering and adds to its mechanical strength [5]. The tomb-chapel is hewn into a brittle fossiliferous chalk which experienced fall downs during the building process being later stuffed with calcium sulphate mortars for surface repairs widely utilized in the 
tombs to improve the resistance avoiding further fall downs. The inside mortars sub-group of the transversal hall and most external areas are more clean anhydrite while the most internal mortars, e.g., the innermost room or shrine, keeps gypsum remains and include a larger proportion of agglomerates, i.e., calcite, quartz and feldspar grains. In these gypsum-based mortars is common to observe euhedral crystals of Celestine $\left(\mathrm{SrSO}_{4}\right)$ (Fig. 5f). Celestine precipitation could be related to the process of gypsification of anhydrite by liberation of strontium and precipitation as euhedral celestine. This could indicate that the original raw material used in the manufacture of these plasters could be anhydrite from the sediments of the Esna formation. Finally, in the burial chamber the ceiling mortar first coating displays a $35 \%$ of calcite, suggesting a possible willingness to improve the ceiling's resistance avoiding further fall downs. Nevertheless, the massive use of gypsum with a $20 \%$ of quartz in the final plastering of the painted burial chamber walls could be explained by the fact that in the high $\mathrm{RH}$ conditions of this chamber the limeputty hardening is very slow. Occasionally this type of mortar and plaster application was used as substrates for decoration, resorting the bad quality of the local limestone as surface for carving and painting. They should be prepared on a surface of plaster upon which the pigment could be applied in tempera rather in fresco secco [5], i.e., they ensured that the pigment adhered to the surface by use of a binding medium without remoistening of the plaster surface. These painted plaster surfaces are common in tomb-chapels on the West Bank at Thebes, where is typical to find it on walls and ceilings and sometimes burial chambers [5].

Analyses of mortars samples collected from the outer courtyard walls and inside the tomb-chapel could additionally provide an insight into the provenance of the materials used by the ancient Egyptian builders to manufacture the different types of mortar. Commonly carbonated mortars show coccolithophore fragments coming from the local rocks, being difficult to elucidate their role as aggregate or relicts of poorly burnt lime-putty under the theoretical necessary $-850^{\circ} \mathrm{C}$ for the thermal decomposition of calcite. The observed nannofossils in both rocks and mortars are exceptional markers to confirm the local origin of Egyptian $\mathrm{CaCO}_{3}$ mortars. These coccoliths of eukaryote phytoplankton are important constituents of the Thebes limestone facies of the central Nile Valley, being studied by coccolith biostratigraphy techniques [34-35]. The mineralogical analyses (Table 3) and the observation under microscopes (Fig. 5) of the aggregate bodies are in good agreement with the previously studied surrounding rocks composed by smectite, illite, kaolinite, sepiolite, calcite, dolomite, quartz, anhydrite and gypsum. Concerning the provenance of the accessorial calcium phosphate minerals found into the mortars, it seems clearly anthropogenic by addition of bones in the raw materials mixtures prior to firings. The Ca-phosphate firing, wetting and re-crystallization processes occurred in different ways producing clean hydroxyapatite or doped with REE associated to 
detritus from endogenous rocks in phases such as monazites and zircons. In short, the materials' provenance points to the near surrounding areas. The high proportion of $\mathrm{Cl}$ and $\mathrm{Br}$ in the carbonated mortar render seems to imply that the water used is much more concentrated in salt than the used for the rest of the mortar.

Finally, the stability of the mortars is related to micro-environmental conditions. Gypsum and lime mortars were found in the funerary complex of Djehuty exhibiting a variety of aggregates, uses and applications. Porosity values for plasters (gypsum mortars) are particularly high (Table 5). The mineralogical composition of the binder is mainly anhydrite, which is the mineral stable phase for the environmental conditions in which they are found and probably the mineral used as raw material prior to application. However, when mortars were applied the original mineralogical composition was gypsum. Along with the time in hot and dry climatic conditions, gypsum slowly transforms into anhydrite. The desiccation from gypsum to anhydrite involves volume reduction and deterioration. Since the molar volume of gypsum and anhydrite are respectively 74.69 and $45.94 \mathrm{~cm}^{3} / \mathrm{mol}$, the dehydration reaction converts gypsum in a $60 \%$ of anhydrite and a $40 \%$ of pore space or porosity. For instance, a mortar with $100 \%$ of anhydrite and a porosity of $50 \%$ (similar to M7) came from a gypsum mortar with circa $17 \%$ of porosity. In the painted burial chamber under moderate levels of relative humidity, gypsum mortars remained well preserved (M30 and M31) since humidity provided a positive effect keeping the gypsum plaster layers in their original conditions preserved from dehydration. The monument's location favoured that the air of the burial chamber originally reached a high relative humidity level circa $80 \%$, in spite of the prevailing drier environmental conditions outside. However, air $\mathrm{RH}$ dropped once the burial chamber was excavated and it is currently oscillating from 40 to $65 \%$ throughout an annual cycle. Nowadays, the burial chamber is kept closed during the archaeological works to maintain stable environmental conditions and avoid desiccation processes. Only it is opened when a specific task needs to be conducted inside.

\section{5.- Summary and conclusions}

The analyses of rock and mortars from the outer courtyard and inside Djehuty's tomb-chapel provided data on the techniques used by the ancient Egyptian builders. The specific properties of the host rock and the local environment play important roles in the construction of funerary monuments and in the evolution of the mortar pastes. The comprehensive knowledge of materials will permit to design mortars compatible with conservation in the funerary complex of Djehuty. These results showed that Djehuty built his tomb-chapel looking for the better mechanical properties of the geological material. Problems of instability 
and falling blocks of geological lower quality levels were solved by applying in each case the appropriate mortar. Furthermore outside the tomb-chapel, several mortar types were applied for setting-up masonry elements as courtyard walls and façade. The sources of the mortar raw materials are local.

The upper level of the tomb-chapel was hewn into a massive limestone with the better mechanical properties. This level was decorated in relief, but mortars were applied onto the host rock to solve fall downs blocks during the building process. These mortars for surface repair are calcium sulphate based mortars, where most external areas are more clean anhydrite while the most internal mortars (shrine) keeps gypsum remains and include more agglomerates proportion, i.e., calcite, quartz and feldspar grains.

The burial chamber was hewn into a limestone level with poorer mechanical properties. The instability of the host rock was solved by applying a first coating plaster layer, a gypsum based mortar but with high proportion of calcite and accessorial quartz. A final aesthetic gypsum plaster layer was applied, on which the Book of the Dead was painted.

The courtyard is delimited by both, rock-carved and masonry walls. The mineral composition in the masonry bedding mortars is variable related to different construction stages, but carbonated bedding mortars prevail. The mud-brick and rock-carved walls were covered by exterior renders. These renders are layered structured. The first carbonated-mud mortar layer is a mixture of limestone, mud and straw fragments. The second fine-grained carbonated mortar layer is mainly composed by calcite and straw, with minor amounts of illite, quartz, dolomite and/or sepiolite. Finally, an outer aesthetic stucco layer is mainly composed by anhydrite.

The specific dry environment outside the tomb-chapel plays an important role in the evolution of the mortar pastes. The mineralogical composition of the raw material of the calcium sulphate binder was anhydrite prior to application and the original mineralogical composition of the calcium sulphate binder was gypsum when were applied onto the walls. But under the hot and dry climatic conditions, outside and in the shallower areas of the tomb, gypsum was again transformed into anhydrite over time. Djehuty's burial chamber is placed close to the water table of the Nile River and originally reached a high relative humidity level circa $80 \%$. Natural gypsum and halite salts infiltrate on the lower half of walls. The high humidity has a positive effect keeping the gypsum plaster layers in their original condition preserving them from dehydration. The burial chamber is closed after each archaeological season and the relative humidity recovers up to 65\%. The micro-environmental conditions are critical to preserve mortars and paintings. Therefore, knowing and stabilizing optimum environmental conditions is essential to ensure the preservation of such materials. 


\section{Acknowledgements}

The archaeological field works in Egypt were supported by the CajaMadrid Foundation (Madrid, Spain). The expedition is now sponsored by Union Fenosa Gas and the Spanish Ministry of Culture. 


\section{References}

[1] Manita P, Triantafillou TC, (2011) Influence of the design materials on the mechanical and physical properties of repair mortars of historic buildings, Materials and Structures 44:1671-1685.

[2] Van Balen K, Papayianni I, Van Hees R, Binda L, Waldum A, (2005) Introduction to requirements for and functions and properties of repair mortars, Materials and Structures 38:781-785.

[3] Válek J, Hughes JJ, Groot C. (2012) Historic mortars: Characterisation, Assessment, Conservation and Repair. Springer. 1-12.

[4] Camuffo D. (2014) Microclimate studies for Cultural Heritage: Conservation, Restoration and Maintenance of Indoor and Outdoor Monuments. $2^{\text {nd }}$ Ed. Elsevier.

[5] Nicholson PT, Shaw I (Eds.) (2006) Ancient Egyptian Materials and Technology. $4^{\text {th }}$ Ed. Cambridge University Press.

[6] Ragaï J, Poyet T, Beurroies I, Rouquerol F, Llewellyn P. (2002) Characterising the porous structure of Egyptian mortars using thermoporometry, mercury intrusion porometry and gas adsorption manometry. Stud Surf Sci Catal 144:435-441.

[7] Lucas A. (2003) Ancient Egyptian Materials and Industries, $4^{\text {th }}$ ed. JR Harris, Edward Arnold.

[8] Garcia-Guinea J, Sanchez-Moral S, Correcher V, Sanchez-Muñoz L, Cuezva S, Cremades A, Benavente D, Galan JM (2008) Phosphor plasters of CaSO4:Dy on the courtyard wall of Djehuty's tomb (Luxor, Egypt), Radiation Meas 43:849-53.

[9] Mahmoud H (2009) Examination of Some Inorganic Pigments and Plaster Layers from Excavations at Saqqara Area, Egypt: Optical microscopy and SEM-EDS microanalysis. E-Conservation Mag 12:38-46.

[10] Sanchez-Moral S, Martinez-Martinez J, Benavente D, Cuezva S, Fernandez-Cortes A (2011) Mechanical characterization of ancient Egyptian mortars, Key Eng Mat 465:487-490.

[11] Pinińska J, Attia HR (2003) Use of geomechanical research in the conservation of stone monuments (Maadi Town Temple, Fayoum, Egypt). Geol Quarterly 47:1-12.

[12] Hemeda S (2013) Geomechanical investigations for architectural heritage preservation, The habib sakakini palace in Cairo, Egypt. Int J Conserv Sci 4:43-52. 
[13] Moussa AMA, Kantiranis N, Voudouris KS, Stratis JA, Ali MF, Christaras V (2009) The impact of soluble salts on the deterioration of Pharaonic and Coptic wall paintings at Al Qrna, Egypt: Mineralogy and chemistry. Archaeometry 51:292-308.

[14] Moussa AB, Kantiranis N, Voudouris KS, Stratis JA, Ali MF, Christaras V (2009) Diagnosis of weathered Coptic wall paintings in the Wadi El Natrun region, Egypt J Cult Herit 10:152-157.

[15] Maekawa S (1993) Environmental monitoring at the Tomb of Nefertari. In: Corzo MA, Afshar M, editors. Art and eternity: the Nefertari wall paintings conservation project, 1986-1992.

[16] Papayianni I, Pachta V, Stefanidou M (2013) Analysis of ancient mortars and design of compatible repair mortars: The case study of Odeion of the archaeological site of Dion. Constr Build Mater 40:84-92.

[17] Bartz W, Rogó J, Rogal R, Cupa A, Szroeder P (2012) Characterization of historical lime plasters by combined non-destructive and destructive tests: The case of the sgraffito in Bonów (SW Poland). Constr Build Mater 30:439446.

[18] Rossi-Doria PR (1990) Report on the RILEM Workshop "Ancient mortars and mortars for restoration" taken place in Ravello (Italy), 9-11 November, 1988, Mater Struc 23:235-238.

[19] Groot C, Ashall G, Hughes JJ (eds.) (2004) Characterization of old mortars with respect to their repair. Final Report of RILEM TC 167-COM. RILEM Publications SARL, Bagneux, France.

[20] Hughes JJ (2012) RILEM TC 203-RMH: Repair mortars for historic masonry. The role of mortar in masonry: an introduction to requirements for the design of repair mortars. Mater Struct 45:1287-1294.

[21] Moropoulou A, Bakolas A, Anagnostopoulou. (2005) Composite materials in ancient structures. Cem Concr Compos 27:295-300.

[22] Galan JM (2009) Early Investigations in the Tomb-Chapel of Djehuty (TT 11). In: Magee D Bourriau J and Quirke S editors. Sitting Beside Lepsius: Studies in Honour of Jaromir Malek at the Griffith Institute. OLA 185:155-181.

[23] Galán JM (2013) The Book of the Dead in the burial chamber of Djehuty (TT 11), Egypt Archaeol 42:21-24.

[24] Said R (1990) The geology of Egypt Ed. A.A. Balkema. Rotterdam. 
[25] Tawfik HA, Zahran EK (2011) Abdel-Hameed AT, Maejima W. Mineralogy, petrography, and biostratigraphy of the Lower Eocene succession at Gebel El-Qurn, West Luxor, Southern Egypt. Arab J Geosci 4:517-534.

[26] Shaaban MN (2004) Diagenesis of the lower Eocene Thebes Formation, Gebel Rewagen area, Eastern Desert, Egypt, Sedim Geol 165:53-65.

[27] Wüst RAJ, McLane J. (2000) Rock derioration in the royal tomb of Seti I, Valley of the Kings, Luxor, Egypt, Eng Geol 58:163-190.

[28] National Climatic Data Center/NESDIS/NOAA/U.S. (2003): U.S.A.F. DATSAV3 Surface Observations, 1901-continuing. Research Data Archive at the National Center for Atmospheric Research, Computational and Information Systems Laboratory. http://rda.ucar.edu/datasets/ds463.2/.

[29] Benavente D, Cultrone G, Gomez-Heras M (2008) The combined influence of mineralogy, hydric and thermal properties in the durability of porous building stones. Eur J Min 20:673-685.

[30] Nakhla SM, Abd El Kader M (2006) Mortars and stones for the restoration of masonry works in the Sphinx. In: Daoud K, Abd el-Fatah S, editors. The World of Ancient Egypt. Essays in Honor of Ahmed Abd el-Qader el-Sawi. Supplément aux Annales du Service des Antiquités de l'Egypte, Cahier no, 35. p.207-15.

[31] Blanc P, Baumer A, Cesbron F, Ohnenstetter D, Panczer G, Remond G. (2000) Systematic cathodoluminescence spectral analysis of synthetic doped minerals: anhydrite, apatite, calcite, fluorite, scheelite and zircon. In: Pagel M, Barbin V, Blanc $P$, Ohnenstetter $D$, editors. Cathodoluminescence in geosciences. Berlin:Springer Verlag. p.127-160.

[32] Benavente D, Sanchez-Moral S, Cortes-Fernandez A, Cañaveras JC, Elez J, Saiz-Jimenez C (2011) Salt damage and microclimate in the Postumius Tomb, Roman Necropolis of Carmona, Spain. Env Earth Sci 63:1529-1543.

[33] Charola AE, Pühringer J, Steiger M (2007) Gypsum: a review of its role in the deterioration of building materials. Environ Geol 52:207-220.

[34] Tantawy, AAAM (2006) Calcareous nannofossils of the Paleocene-Eocene transition at Qena region, central Nile Valley, Egypt. Micropaleontol 52:193222.

[35] Aubry MP, Salem R. (2012) The Dababiya Core: A window into Paleocene to Early Eocene depositional history in Egypt based on coccolith. Stratigr 9:287-346. 


\section{FIGURE CAPTIONS}

Figure 1. TT11 Djehuty Tomb-chapel in Luxor (Egypt): Geological map of the surrounding area and horizontal sketch.

Figure 2. Vertical sketch section of Djehuty tomb-chapel including stratigraphic location of its five geological column sections and the lithotological and paleontological description.

Figure 3. Pore-size distribution curves of host rocks for the different geological sections.

Figure 4. Photographs of the different types of mortar on the funerary complex of Djehuty: a) Bedding mortar (M4) for setting masonry units (mud-bricks), b) Exterior render mortars showing the first mortar-coating layer (M2), the second mortar coating-layer (M3) and the final aesthetic layer (M8), c) Surface repair mortar (M6) used for the replacement of a block of fallen rock during the carving of the tomb-chapel. d) Djehuty sculpture carved directly in the host-rock (S4). The recess on the wall for holding the sculpture is covered by a hard mortar (M23) including huntite as bleaching agent on the outer surface (M24). e) Nut represented in the centre of the ceiling of the painted burial chamber. A leveller layer of mortar is applied directly on the lowered and smoothen ceiling (M29). This layer is covered by a final plaster layer (M30).

Figure 5. Photomicrographs taken under the ESEM: (a) Calcite fragment from the S4 of the geological column exhibiting coccolithophores; (b) carbonatic bedding mortar sample (M4) including fragments of coccolithophores; (c) carbonatic exterior render (M3) exhibiting straw and Coccolithus fragments; (d) calcium sulphate exterior render mortar sample (M88-7) consisting of anhydrite binder; (e) surface repair mortar sample (M28) composed of anhydrite as binder and detrital quartz and feldspar grains; (f) surface repair mortar sample (M5) with a celestine crystal in detail.

Figure 6. Cumulative mercury intrusion and pore-size distribution curves of mortars M4, M6, M11 and M15.

\section{TABLE CAPTIONS}

Table 1. Setting, use, colour, texture, and RILEM functional classifications of collected samples.

Table 2. Value averages of the main physical, chemical and mineralogical properties by sections of the geological column.

Table 3. Mineralogical semi-quantitative DRX analyses of mortars. 
Table 4. XRF analyses of mortar samples.

Table 5. Connected porosity, $\mathrm{P}$, total porosity, $\mathrm{P}_{\mathrm{T}}$, and specific surface area, $\mathrm{SSA}\left(\mathrm{m}^{2} / \mathrm{g}\right)$, measurements of the mortar samples. 


\begin{tabular}{|c|c|c|c|c|c|c|c|c|}
\hline \multirow[b]{2}{*}{ Mortar type } & \multirow[b]{2}{*}{ Sample } & \multirow[b]{2}{*}{ Setting } & \multirow[b]{2}{*}{ Building element } & \multirow[b]{2}{*}{ Technical application } & \multirow[b]{2}{*}{$\begin{array}{l}\text { Mortar } \\
\text { color }\end{array}$} & \multirow[b]{2}{*}{$\begin{array}{l}\text { Mortar } \\
\text { texture }\end{array}$} & \multicolumn{2}{|c|}{ RILEM functional mortar classifications } \\
\hline & & & & & & & $\begin{array}{c}\text { RILEM TC 203-RMH } \\
{[24]}\end{array}$ & RILEM Workshop 1988 [22] \\
\hline \multirow[t]{7}{*}{$\begin{array}{l}\text { Bedding } \\
\text { mortar }\end{array}$} & M4 & Open courtyard: West wall & Mud-brick masonry wall & Setting and adhesion & Beige & $\begin{array}{l}\text { Intermediate } \\
\text {-coarse }\end{array}$ & Bedding mortar & Masonry mortars:(i) bedding \\
\hline & M21 & Open courtyard: West wall & Mud-brick masonry wall & Setting and adhesion & Beige & Coarse & Bedding mortar & Masonry mortars:(i) bedding \\
\hline & M35 - M41 & Open courtyard: West wall & Mud-brick masonry wall & Setting and adhesion & grey-crem & intermediate & Bedding mortar & Masonry mortars:(i) bedding \\
\hline & $\mathrm{M} 43-\mathrm{M} 44$ & Open courtyard: West wall & Mud-brick masonry wall & Setting and adhesion & grey-crem & intermediate & Bedding mortar & Masonry mortars:(i) bedding \\
\hline & M45 - M46 & Open courtyard: West wall & Mud-brick masonry wall & Setting and adhesion & grey-crem & \begin{tabular}{|l|} 
Intermediate \\
-coarse \\
\end{tabular} & Bedding mortar & Masonry mortars:(i) bedding \\
\hline & M49- M50 & Open courtyard: West wall & Mud-brick masonry wall & Setting and adhesion & grey-crem & $\begin{array}{l}\text { Intermediate } \\
\text {-coarse }\end{array}$ & Bedding mortar & Masonry mortars:(i) bedding \\
\hline & M52 & Open courtyard: West wall & Mud-brick masonry wall & Setting and adhesion & grey-crem & $\begin{array}{l}\text { Intermediate } \\
\text {-coarse }\end{array}$ & Bedding mortar & Masonry mortars:(i) bedding \\
\hline \multirow[t]{15}{*}{$\begin{array}{l}\text { Exterior } \\
\text { render }\end{array}$} & M2 & Open courtyard: West wall & $\begin{array}{l}\text { Rock carved/masonry } \\
\text { wall }\end{array}$ & $\begin{array}{l}\text { 1st mortar-coating layer, } \\
\text { for flattening }\end{array}$ & brown dark & coarse & Exterior render & $\begin{array}{l}\text { Mortars for the application of } \\
\text { facings: ii) walls }\end{array}$ \\
\hline & M16 & Open courtyard: East wall & Rock masonry wall & $\begin{array}{l}\text { 1st mortar-coating layer, } \\
\text { for flattening }\end{array}$ & brown dark & coarse & Exterior render & $\begin{array}{l}\text { Mortars for the application of } \\
\text { facings: ii) walls }\end{array}$ \\
\hline & M3 & Open courtyard: West wall & $\begin{array}{l}\text { Rock carved/masonry } \\
\text { wall }\end{array}$ & $\begin{array}{l}\text { 2nd mortar-coating layer, } \\
\text { for smoothing }\end{array}$ & brown pale & intermediate & Exterior render & $\begin{array}{l}\text { Mortars for the application of } \\
\text { facings: ii) walls }\end{array}$ \\
\hline & M12 & Open courtyard: West wall & Mud-brick masonry wall & $\begin{array}{l}\text { Single mortar-coating } \\
\text { layer, for smoothing }\end{array}$ & brown pale & intermediate & Exterior render & $\begin{array}{l}\text { Mortars for the application of } \\
\text { facings: ii) walls }\end{array}$ \\
\hline & M13 & Open courtyard: West wall & Mud-brick masonry wall & $\begin{array}{l}2^{\text {nd }} \text { mortar-coating layer, } \\
\text { for smoothing }\end{array}$ & brown pale & intermediate & Exterior render & $\begin{array}{l}\text { Mortars for the application of } \\
\text { facings: ii) walls }\end{array}$ \\
\hline & M14 & Open courtyard: East wall & Rock masonry wall & $\begin{array}{l}\text { 2n }^{\text {nd }} \text { mortar-coating layer, } \\
\text { for smoothing }\end{array}$ & brown pale & intermediate & Exterior render & $\begin{array}{l}\text { Mortars for the application of } \\
\text { facings: ii) walls }\end{array}$ \\
\hline & M15 & Open courtyard: East wall & Rock masonry wall & $\begin{array}{l}2^{\text {nd }} \text { mortar-coating layer, } \\
\text { for smoothing }\end{array}$ & brown pale & intermediate & Exterior render & $\begin{array}{l}\text { Mortars for the application of } \\
\text { facings: ii) walls }\end{array}$ \\
\hline & M20 & Open courtyard: West wall & $\begin{array}{l}\text { Rock carved/masonry } \\
\text { wall }\end{array}$ & $\begin{array}{l}2^{\text {nd }} \text { mortar-coating layer, } \\
\text { for smoothing }\end{array}$ & brown pale & intermediate & Exterior render & $\begin{array}{l}\text { Mortars for the application of } \\
\text { facings: ii) walls }\end{array}$ \\
\hline & M8 & $\begin{array}{l}\text { Open courtyard: Western } \\
\text { wall }\end{array}$ & $\begin{array}{l}\text { Rock carved/masonry } \\
\text { wall }\end{array}$ & Aesthetic layer & white & fine & Exterior render & $\begin{array}{l}\text { Mortars for decoration: } \\
\text { (i) layered }\end{array}$ \\
\hline & M8-07 & $\begin{array}{l}\text { Open courtyard: Western } \\
\text { wall }\end{array}$ & Mud-brick masonry wall & Aesthetic layer & white & fine & Exterior render & $\begin{array}{l}\text { Mortars for decoration: } \\
\text { (i) layered }\end{array}$ \\
\hline & M88-08 & $\begin{array}{l}\text { Open courtyard: Western } \\
\text { wall }\end{array}$ & Mud-brick masonry wall & Aesthetic layer & white & fine & Exterior render & $\begin{array}{l}\text { Mortars for decoration: } \\
\text { (i) layered }\end{array}$ \\
\hline & M9 & North façade wall & Rock masonry wall & Aesthetic layer & Grey / white & fine & Exterior render & $\begin{array}{l}\text { Mortars for decoration: } \\
\text { (i) layered }\end{array}$ \\
\hline & M10 & North façade wall & Rock masonry wall & Aesthetic layer & Grey / white & fine & Exterior render & $\begin{array}{l}\text { Mortars for decoration: } \\
\text { (i) layered }\end{array}$ \\
\hline & M11 & North façade wall & Rock masonry wall & Aesthetic layer & Grey / white & fine & Exterior render & $\begin{array}{l}\text { Mortars for decoration: } \\
\text { (i) layered }\end{array}$ \\
\hline & M22 & Open courtyard: UE-17 well & Mud-brick masonry wall & Aesthetic layer & white & fine & Exterior render & $\begin{array}{l}\text { Mortars for decoration: } \\
\text { (i) layered }\end{array}$ \\
\hline \multirow[t]{9}{*}{$\begin{array}{l}\text { Surface } \\
\text { repair }\end{array}$} & M5 & $\begin{array}{l}\text { Open courtyard: West } \\
\text { façade }\end{array}$ & Rock carved wall & $\begin{array}{l}\text { Rock fallen } \\
\text { replacement/gap filling }\end{array}$ & white & $\begin{array}{l}\text { fine- } \\
\text { intermediate }\end{array}$ & $\begin{array}{l}\text { Mortars for surface } \\
\text { repairs }\end{array}$ & Special mortars for repairs \\
\hline & M6 & $\begin{array}{l}\text { Open courtyard: West } \\
\text { façade }\end{array}$ & Rock carved wall & $\begin{array}{l}\text { Rock fallen } \\
\text { replacement/gap filling }\end{array}$ & white & $\begin{array}{l}\text { fine- } \\
\text { intermediate }\end{array}$ & $\begin{array}{l}\text { Mortars for surface } \\
\text { repairs }\end{array}$ & Special mortars for repairs \\
\hline & M23 & Open courtyard Hall & Djehuty sculpture & $\begin{array}{l}\text { Replacement } \\
\text { anddecoration }\end{array}$ & Grey / white & fine & $\begin{array}{l}\text { Mortars for surface } \\
\text { repairs }\end{array}$ & Special mortars for repairs \\
\hline & M1 & Transverse corridor. SE wall & Rock carved wall & $\begin{array}{l}\text { Rock fallen } \\
\text { replacement/gap filling }\end{array}$ & white & $\begin{array}{l}\text { fine- } \\
\text { intermediate }\end{array}$ & $\begin{array}{l}\text { Mortars for surface } \\
\text { repairs }\end{array}$ & Special mortars for repairs \\
\hline & M7 & Transverse corridor. NE wall & Rock carved wall & \begin{tabular}{|l|} 
Rock fallen \\
replacement/gap filling \\
\end{tabular} & white & coarse & $\begin{array}{l}\text { Mortars for surface } \\
\text { repairs }\end{array}$ & Special mortars for repairs \\
\hline & M28 & Central corridor. West wall & Rock carved wall & $\begin{array}{l}\text { Replacement and rock } \\
\text { fallen clamping } \\
\end{array}$ & Grey / white & $\begin{array}{l}\text { intermediate } \\
\text {-coarse }\end{array}$ & $\begin{array}{l}\text { Mortars for surface } \\
\text { repairs }\end{array}$ & Special mortars for repairs \\
\hline & M25 & Shrine: West wall & Rock carved wall & $\begin{array}{l}\text { Replacement and rock } \\
\text { fallen clamping }\end{array}$ & Grey / white & coarse & $\begin{array}{l}\text { Mortars for surface } \\
\text { repairs }\end{array}$ & Special mortars for repairs \\
\hline & M26 & Shrine: West wall & Rock carved wall & $\begin{array}{l}\text { Replacement and } \\
\text { decoration }\end{array}$ & white & fine & $\begin{array}{l}\text { Mortars for surface } \\
\text { repairs }\end{array}$ & Special mortars for repairs \\
\hline & M27 & Shrine: West wall & Rock carved wall & $\begin{array}{l}\text { Replacement and rock } \\
\text { fallen clamping }\end{array}$ & Grey / white & coarse & $\begin{array}{l}\text { Mortars for surface } \\
\text { repairs }\end{array}$ & Special mortars for repairs \\
\hline \multirow{3}{*}{$\begin{array}{l}\text { Interior } \\
\text { plasters and } \\
\text { coatings }\end{array}$} & M29 & Burial chamber & Rock carved ceiling & $\begin{array}{l}1^{\text {st }} \text { mortar-coating, to } \\
\text { flatten and leveling }\end{array}$ & Grey / white & intermediate & Interior plaster & 1.Mortar for plaster \\
\hline & M30 & Burial Chamber & Rock carved ceiling & Aesthetic layer & Grey / white & fine & Interior plaster & 1.Mortar for plaster \\
\hline & M31 & Burial Chamber & Rock carved wall & Aesthetic layer & grey-crem & intermediate & Interior plaster & 1.Mortar for plaster \\
\hline $\begin{array}{l}\text { Mortar for } \\
\text { decoration }\end{array}$ & M24 & Open courtyard Hall & Djehuty sculpture & Sculpture coatings & white & fine & \begin{tabular}{|l}
- \\
\end{tabular} & $\begin{array}{l}\text { 3.Mortars for decoration: } \\
\text { (i) layered }\end{array}$ \\
\hline
\end{tabular}




\begin{tabular}{|c|c|c|c|c|c|}
\hline & & Section 1 & Section 2 & Section 3 & Section 4 \\
\hline \multirow{4}{*}{ Mineralogical composition (\%) } & Calcite & $85-90$ & $75-80$ & $65-70$ & $85-90$ \\
\hline & Dolomite & $1-5$ & $5-10$ & $15-20$ & $1-5$ \\
\hline & Quartz & $1-5$ & $5-10$ & $5-10$ & $5-10$ \\
\hline & Phyllosilicates (mainly Illite) & $1-5$ & $<1$ & $5-10$ & - \\
\hline \multirow{12}{*}{$\begin{array}{l}\text { Chemical composition, } \\
\text { minor elements (\%) }\end{array}$} & $\mathrm{SiO}_{2}$ & 9.06 & 11,40 & 12.74 & 11.26 \\
\hline & $\mathrm{Al}_{2} \mathrm{O}_{3}$ & 2.63 & 2,01 & 2.78 & 1.09 \\
\hline & $\mathrm{Fe}_{2} \mathrm{O}_{3}$ (total) & 0.96 & 1,23 & 1.39 & 0.82 \\
\hline & $\mathrm{MnO}$ & 0.01 & 0,01 & 0.01 & 0.01 \\
\hline & $\mathrm{MgO}$ & 1.39 & 1,84 & 2.37 & 1.36 \\
\hline & $\mathrm{CaO}$ & 44.91 & 43,30 & 42.75 & 44.98 \\
\hline & $\mathrm{Na}_{2} \mathrm{O}$ & 0.54 & 0,59 & 0.59 & 0.48 \\
\hline & $\mathrm{SO}_{3}$ & 0.19 & 0,32 & 0.41 & 0.27 \\
\hline & $\mathrm{K}_{2} \mathrm{O}$ & 0.36 & 0,40 & 0.39 & 0.13 \\
\hline & $\mathrm{TiO}_{2}$ & 0.08 & 0,09 & 0.08 & 0.03 \\
\hline & $\mathrm{P}_{2} \mathrm{O}_{5}$ & 0.57 & 0,75 & 0.68 & 0.31 \\
\hline & LOI & 39.22 & 38,00 & 35.50 & 39.13 \\
\hline \multirow{4}{*}{ Pore structure properties } & Total porosity (He) (\%) & 18.90 & 20.40 & 29.48 & 33.35 \\
\hline & Connected porosity $(\mathrm{Hg})(\%)$ & 16.90 & 17.59 & 25.95 & 30.26 \\
\hline & Mean radius $(\mathrm{Hg})(\mu \mathrm{m})$ & 0.057 & 0.063 & 0.094 & 0.157 \\
\hline & Specific surface area, SSA $\left(\mathrm{N}_{2}\right)\left(\mathrm{m}^{2} / \mathrm{g}\right)$ & 6.02 & 3.44 & 5.72 & 3.28 \\
\hline Mechanical properties & Compresive strength (MPa) & 17.20 & 26.63 & 13.82 & 30.51 \\
\hline
\end{tabular}




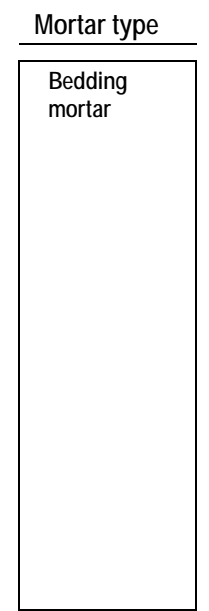

\begin{tabular}{|c|c|c|c|c|c|c|c|c|}
\hline Sample & Gypsum & Anhydrite & Calcite & Illite & Quartz & Feldspar & Sepiolite & Dolomite \\
\hline M4 & -- & - & 94 & -- & 3 & -- & - & 4 \\
\hline M21 & 11 & 2 & 43 & 8 & 13 & 19 & 5 & - \\
\hline M35 & -- & 3 & 33 & 16 & 18 & 29 & - & 2 \\
\hline M36 & -- & -- & 59 & 15 & 21 & -- & -- & 6 \\
\hline M37 & -- & 3 & 46 & 14 & 20 & 5 & - & 12 \\
\hline M39 &.- & 7 & 55 & -- & 14 & 12 & 5 & 7 \\
\hline M40 & -- & 5 & 56 & 14 & 21 & -- & -- & 4 \\
\hline M41 & -- & 5 & 52 & 13 & 27 & -- & - & 3 \\
\hline M43 & -- & 53 & 38 & -- & 4 & -- & 1 & 5 \\
\hline M44 & -- & 28 & 30 & 9 & 13 & 11 & 4 & 5 \\
\hline M45 & -- & -- & 24 & 22 & 30 & 16 & 8 & -- \\
\hline M46 & -- & -- & 25 & 13 & 17 & 12 & 29 & 5 \\
\hline M49 & -- & 46 & 35 & -- & 12 & -- & 7 & -- \\
\hline M50 & - & 52 & 25 & 8 & 7 & -- & 5 & 3 \\
\hline M52 & - & 4 & 70 & 9 & 17 & - & - & -- \\
\hline
\end{tabular}

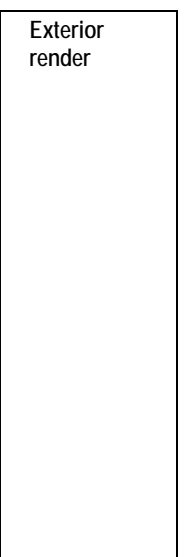

\begin{tabular}{|l|r|r|r|r|r|r|r|r|}
\hline M2 & -- & -- & 37 & 34 & 17 & 7 & 2 & 4 \\
\hline M16 & -- & -- & 48 & 4 & 22 & 17 & 8 & -- \\
\hline M3 & -- & -- & 94 & -- & 2 & -- & -- & 4 \\
\hline M12 & -- & 7 & 87 & -- & 6 & -- & -- & -- \\
\hline M13 & 12 & 3 & 74 & -- & 3 & 5 & 3 & -- \\
\hline M14 & -- & -- & 94 & -- & 3 & -- & 2 & 2 \\
\hline M15 & -- & -- & 85 & 10 & 4 & -- & -- & 2 \\
\hline M20 & -- & 2 & 92 & 2 & 2 & -- & -- & 2 \\
\hline M8 & 2 & 92 & 2 & 3 & 1 & -- & -- & -- \\
\hline M8-07 & -- & 99 & 1 & -- & -- & -- & -- & -- \\
\hline M88-07 & -- & 100 & 1 & -- & -- & -- & -- & -- \\
\hline M9 & -- & 89 & 3 & -- & 8 & -- & -- & -- \\
\hline M10 & -- & 95 & 1 & -- & 4 & -- & -- & -- \\
\hline M11 & -- & 84 & 7 & -- & 6 & 4 & -- & - \\
\hline M22 & -- & 98 & 2 & -- & -- & -- & - \\
\hline
\end{tabular}

\section{Surface}

repair

\begin{tabular}{|c|c|c|c|c|c|c|c|c|}
\hline M5 & -- & 93 & 1 & -- & 6 & -- & -- & -- \\
\hline M6 & -- & 89 & 2 & -- & 8 & 2 & -- & -- \\
\hline M23 & $\ldots$ & 88 & 1 &.- & 6 &.- & -- & -- \\
\hline M1 & -. & 90 & 8 & -- & 2 & -- & - & - \\
\hline M7 &.- & 94 & 2 & -- & 4 & -- &.- & -- \\
\hline M28 & 6 & 79 & 3 & -- & 6 & 6 & -- & - \\
\hline $\mathrm{M} 25$ & 3 & 69 & 11 & -- & 16 & 1 & -- & - \\
\hline M26 & 4 & 67 & 7 & -- & 15 & 7 & -- & - \\
\hline M27 & 9 & 71 & 7 & -- & 10 & 4 & -- & -- \\
\hline
\end{tabular}

\section{Interior}

plasters and

coatings

\begin{tabular}{|c|c|c|c|c|c|c|c|c|}
\hline M29 & 48 & - & 35 & -- & 17 & -- &.- & - \\
\hline M30 & 71 & 10 & -- & -- & 19 & - &.- & -- \\
\hline M31 & 87 & $\ldots$ & -1 & -- & 13 & - & .- & - \\
\hline & Gypsum & Anhidrite & Calcite & Huntite & Quartz & Feldespar & Sepiolite & Dolomite \\
\hline M24 & -. & 13 & 68 & 15 & 3 & -- & -- & 2 \\
\hline
\end{tabular}

Mortar fo

decoration 
Mortar type

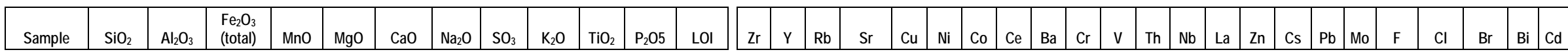

\begin{tabular}{|c|c|c|c|c|c|c|c|c|c|c|c|c|c|c|c|c|c|c|c|c|c|c|c|c|c|c|c|c|c|c|c|c|c|c|c|c|c|}
\hline $\begin{array}{l}\text { Bedding } \\
\text { mortar }\end{array}$ & M21 & 30.81 & 7.46 & 4.43 & 0.05 & 2.84 & 28.99 & 0.75 & 0.21 & 0.94 & 0.68 & 0.39 & 22.61 & 105 & 16 & 13 & 401 & 12 & 24 & 10 & 15 & 184 & 63 & 74 & 3 & 8 & 1 & & 33 & 4 & 3 & & 745 & 794 & 10 & & 19 \\
\hline \multirow{9}{*}{$\begin{array}{l}\text { Exterior } \\
\text { render }\end{array}$} & M16 & 42.47 & 10.43 & 6.87 & 0.10 & 3.03 & 16.49 & 1.07 & 0.20 & 1.21 & 1.20 & 0.32 & 16.28 & 237 & 26 & 29 & 448 & 31 & 47 & 18 & 51 & 339 & 116 & 13 & 11 & 2 & 2 & & 66 & 1 & 6 & 1 & 616 & $\mid 1957$ & 929 & 8 & \\
\hline & M12 & 14.15 & 3.58 & 1.69 & 0.01 & 2.05 & 41.13 & 0.73 & 1.04 & 0.76 & 0.17 & 0.52 & 34.18 & 47 & 31 & 10 & 862 & 7 & 22 & 8 & 14 & 199 & 69 & 35 & 8 & 6 & 1 & & 32 & 10 & - & - & 1006 & 10350 & 2409 & 9 & \\
\hline & M13 & 14.11 & 3.33 & 1.52 & 0.01 & 2.03 & 40.92 & 1.02 & 1.61 & 0.58 & 0.16 & 0.53 & 34.18 & 58 & 35 & 11 & 957 & 10 & 24 & 8 & 21 & 161 & 72 & 35 & - & 2 & 1 & & 33 & 2 & 3 & - & 1140 & 8039 & 3087 & 9 & 1 \\
\hline & M14 & 14.15 & 4.21 & 1.65 & 0.01 & 2.10 & 41.07 & 0.91 & 0.25 & 0.62 & 0.16 & 0.47 & 34.60 & 59 & 30 & 13 & 846 & 11 & 27 & 8 & 20 & 291 & 93 & 39 & & 4 & 1 & & 38 & 1 & 2 & - & $\mid 1124$ & 2788 & 1921 & 12 & \\
\hline & M15 & 13.19 & 4.17 & 1.55 & 0.01 & 2.08 & 41.31 & 1.31 & 0.22 & 0.60 & 0.15 & 0.46 & 35.13 & 59 & 28 & 14 & 817 & 9 & 26 & 7 & 18 & 154 & 93 & 40 & - & 1 & 1 & & 37 & 1 & 1 & - & 1087 & 2233 & 4521 & 16 & 1 \\
\hline & M20 & 12.86 & 3.68 & 1.62 & 0.01 & 2.12 & 47.03 & 0.83 & 0.40 & 0.68 & 0.16 & 0.59 & 29.98 & 29 & 16 & 9 & 432 & 4 & 15 & 7 & 2 & 49 & 43 & 39 & - & 2 & $\varepsilon$ & & 26 & 4 & 1 & - & 944 & |6027 & 1427 & 14 & - \\
\hline & M9 & 12.02 & 2.70 & 1.79 & 0.02 & 1.85 & 36.62 & 0.68 & |38.41 & 0.23 & 0.17 & 0.19 & 5.31 & - & 4 & - & 3983 & 4 & 12 & 9 & 21 & 142 & 33 & 18 & - & 7 & . & & 11 & 7 & 1 & - & 388 & 806 & 7 & 1 & - \\
\hline & M10 & 11.27 & 2.54 & 1.73 & 0.02 & 1.81 & 37.15 & 0.97 & 39.94 & 0.24 & 0.16 & 0.17 & 3.79 & & 4 & - & 3817 & 2 & 10 & 10 & 13 & 111 & 24 & 19 & & 1 & 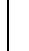 & & 10 & 8 & 1 & & 581 & 2111 & 8 & 1 & \\
\hline & M11 & 14.84 & 3.09 & 1.85 & 0.02 & 1.94 & 35.14 & 0.86 & |33.37 & 0.29 & 0.21 & 0.21 & 7.99 & - & 2 & - & 2170 & 3 & 11 & 7 & 1 & 84 & 27 & 20 & - & 2 & 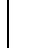 & & 12 & 9 & 1 & - & 515 & 1239 & 10 & 1 & 13 \\
\hline \multirow[t]{2}{*}{$\begin{array}{l}\text { Surface } \\
\text { repair }\end{array}$} & M25 & 15.70 & 2.30 & 0.93 & 0.09 & 1.92 & 25.34 & 0.25 & 39.36 & 0.14 & 0.11 & 0.18 & 13.32 & - & 4 & - & 3051 & 8 & 14 & 8 & 18 & 301 & 64 & 26 & - & 1 & 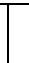 & & 16 & 22 & 7 & - & 897 & 579 & 5 & - & - \\
\hline & M27 & 26.47 & 1.67 & 0.87 & 0.02 & 1.68 & 18.35 & 0.31 & 30.39 & 0.23 & 0.13 & 0.13 & 19.20 & 23 & 5 & - & 2967 & - & 10 & 9 & 22 & 359 & 72 & 24 & 1 & 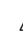 & 1 & & 14 & 13 & 5 & - & 586 & 484 & 4 & - & - \\
\hline \multirow{2}{*}{$\begin{array}{l}\text { Interior } \\
\text { plasters } \\
\text { and } \\
\text { coatings }\end{array}$} & M29 & 11.53 & 1.37 & 0.61 & 0.01 & 1.65 & 41.20 & 0.26 & 23.00 & 0.07 & 0.06 & 0.12 & 20.13 & & 1 & - & 2273 & - & 7 & 7 & 13 & 215 & 37 & 16 & - & 3 & 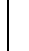 & & 4 & 30 & - & - & 483 & 252 & & & 6 \\
\hline & M31 & 7.69 & 1.95 & 1.28 & 0.00 & 2.60 & 28.09 & 0.27 & 35.70 & 0.13 & 0.12 & 0.11 & 21.77 & 41 & 5 & - & 2944 & - & 7 & 10 & 12 & 272 & 96 & 16 & - & 2 & 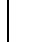 & & - & 28 & 1 & - & - & 210 & - & - & - \\
\hline
\end{tabular}




\begin{tabular}{|c|c|c|c|c|}
\hline Mortar type & Sample & $\mathrm{P}(\%)$ & Pт (\%) & $\mathrm{SSA}\left(\mathrm{m}^{2} / \mathrm{g}\right)$ \\
\hline \multirow{2}{*}{$\begin{array}{l}\text { Bedding } \\
\text { mortar }\end{array}$} & M4 & 31.30 & 34.63 & 18.34 \\
\hline & M21 & 30.89 & 43.73 & 14.37 \\
\hline
\end{tabular}

\begin{tabular}{|c|c|c|c|c|}
\hline \multirow{8}{*}{$\begin{array}{l}\text { Exterior } \\
\text { render }\end{array}$} & M2 & 43.53 & 46.31 & 8.22 \\
\hline & $\mathrm{M} 12$ & 48.89 & 57.49 & 3.49 \\
\hline & M13 & 46.07 & 62.30 & 3.92 \\
\hline & M14 & 43.60 & 47.46 & 10.17 \\
\hline & M15 & 42.05 & 44.57 & 5.03 \\
\hline & M9 & 57.93 & 58.27 & 2.56 \\
\hline & $\mathrm{M} 10$ & 62.05 & 68.56 & 7.56 \\
\hline & M11 & 68.35 & 57.61 & 8.32 \\
\hline
\end{tabular}

\begin{tabular}{|l|l|r|r|r|}
\hline $\begin{array}{l}\text { Surface } \\
\text { repair }\end{array}$ & M5 & 62.89 & 61.80 & 9.05 \\
\hline M6 & 55.77 & 56.56 & 7.33 \\
\hline M1 & 55.16 & 53.62 & 1.00 \\
\hline M7 & 51.11 & 52.10 & 1.88 \\
\hline M25 & 57.94 & 62.77 & 1.10 \\
\hline M26 & 50.42 & - & 2.36 \\
\hline M27 & 52.77 & 56.64 & 2.10 \\
\hline
\end{tabular}




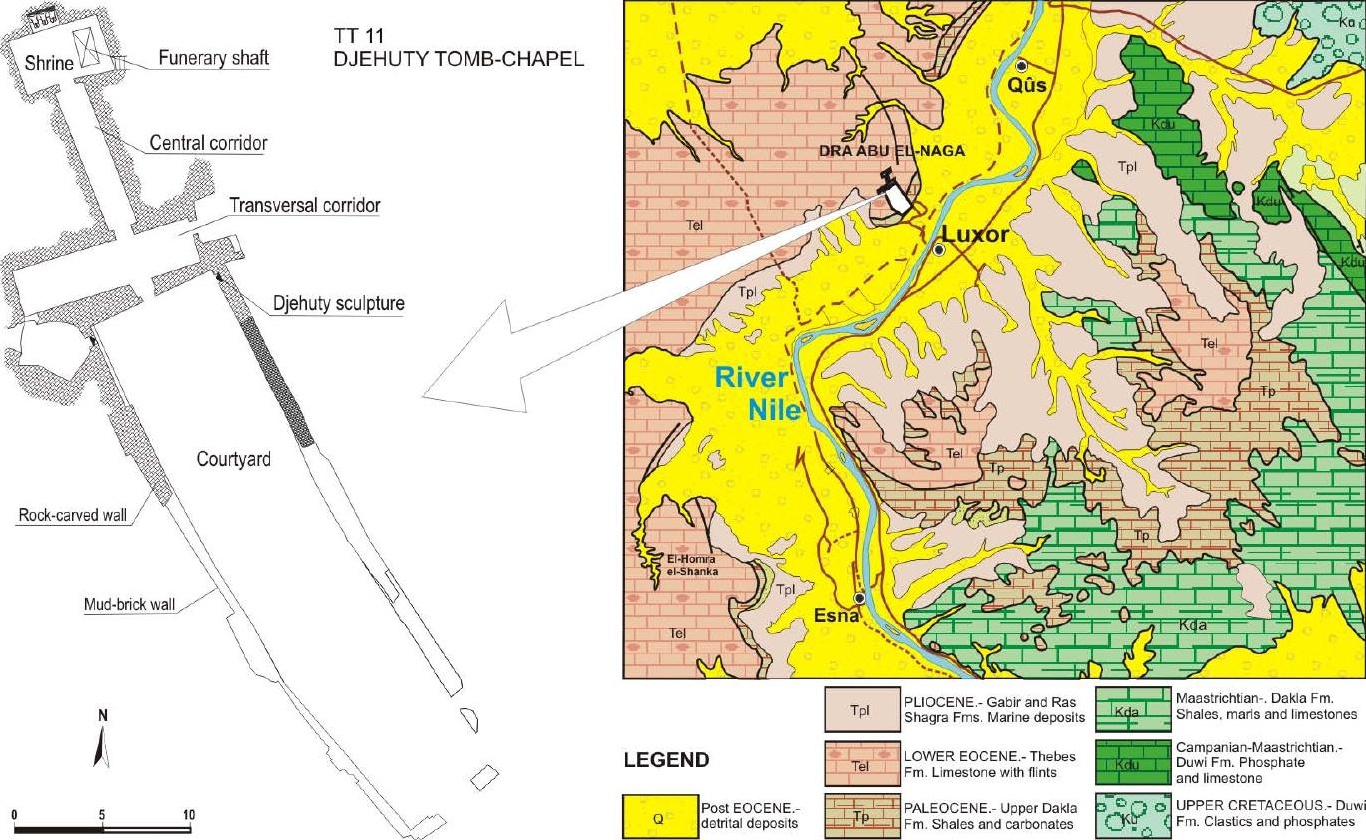


Section 5.- Basement of massive limestone

above it, thin-bedded limestone with chert

nodules, a sheet-bedded marlstone and a

limestone with nodules in the section top.

Section 4.- Pink massive limestone with

alteration rings and many nuclei of iron

oxides

Section 3.- Inter-bedded pink massive

limestone with limestone sheet-beds.

Section 2.- Interbedded strata of massive and nodulose limestones.

Section 1.- Massive white-pale-brown limestone beds in centimetric beds. Vertical fissures infilled by gypsum anc calcite.

$$
\text { calcite. }
$$
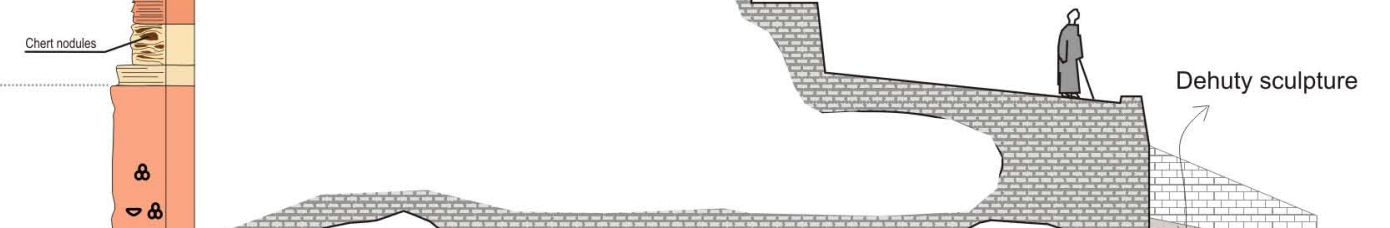

Courtyard

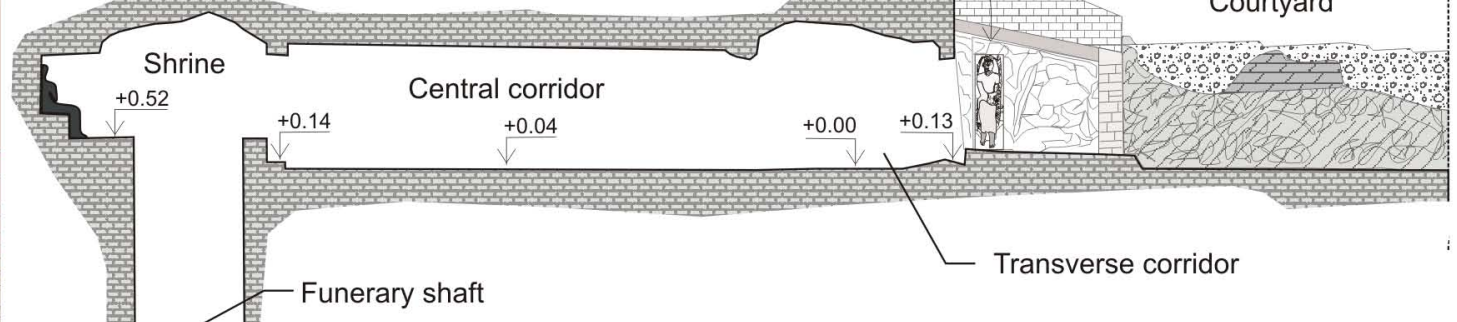

Funerary shaft

Transverse corridor

Bivalve

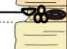

Cocoolithophore

Halite
efflorescence

Gypsum
efflorescence Foraminifera

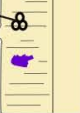

${ }_{0}^{1 \mathrm{~m}}$

I
$-7.56$

$-8.01$

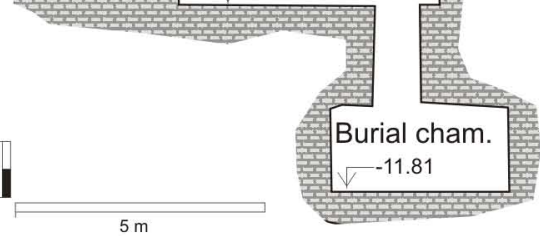

$5 \mathrm{~m}$ 


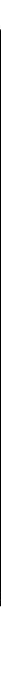




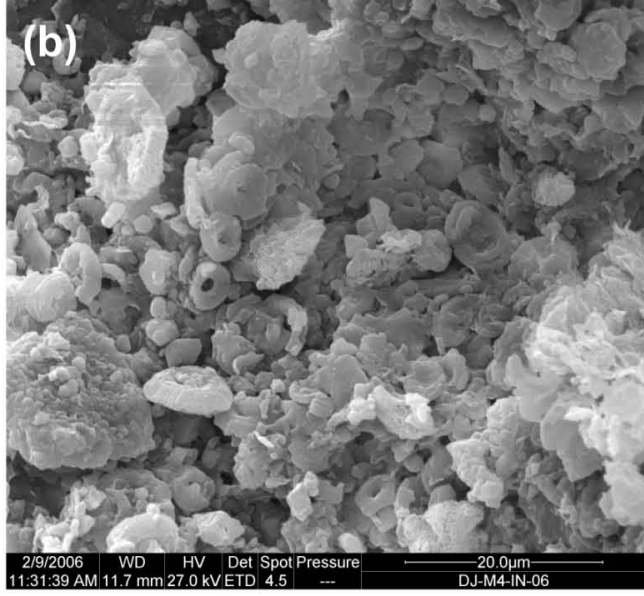

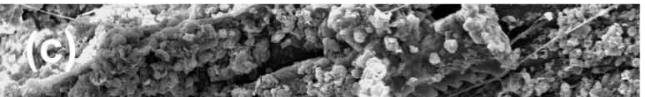
0.4 7 .

W

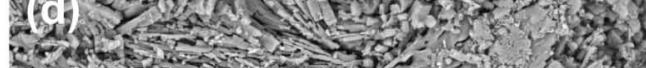

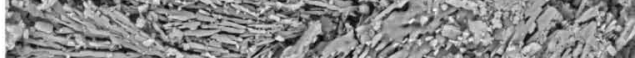
20.350.

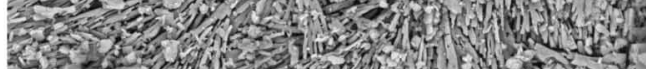
[CE G

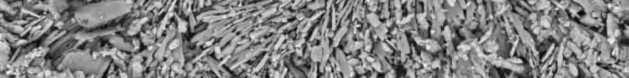

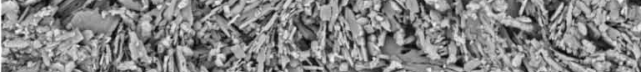

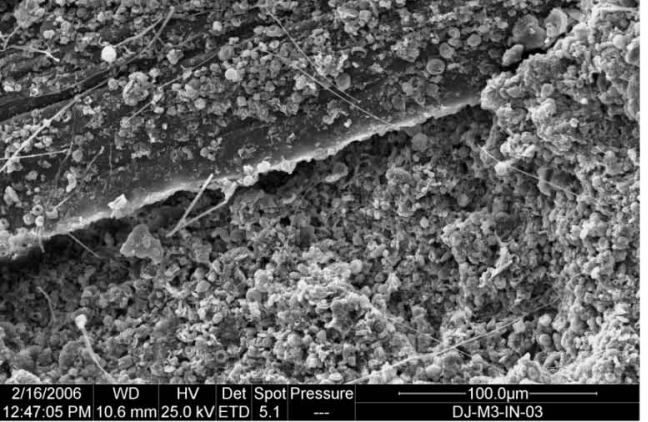

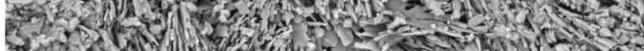

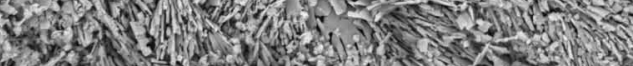
Q 123 . 15 is

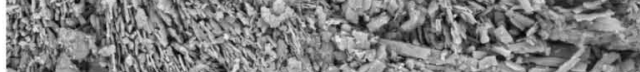

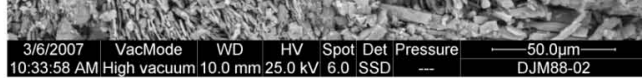
(e)

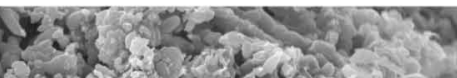

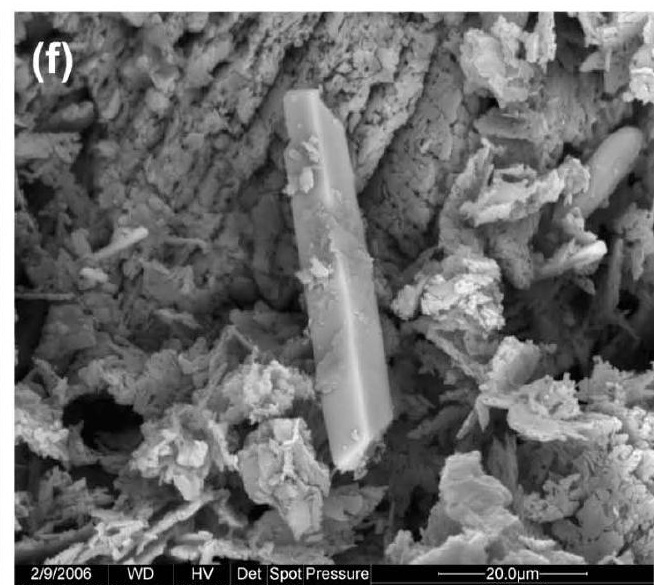




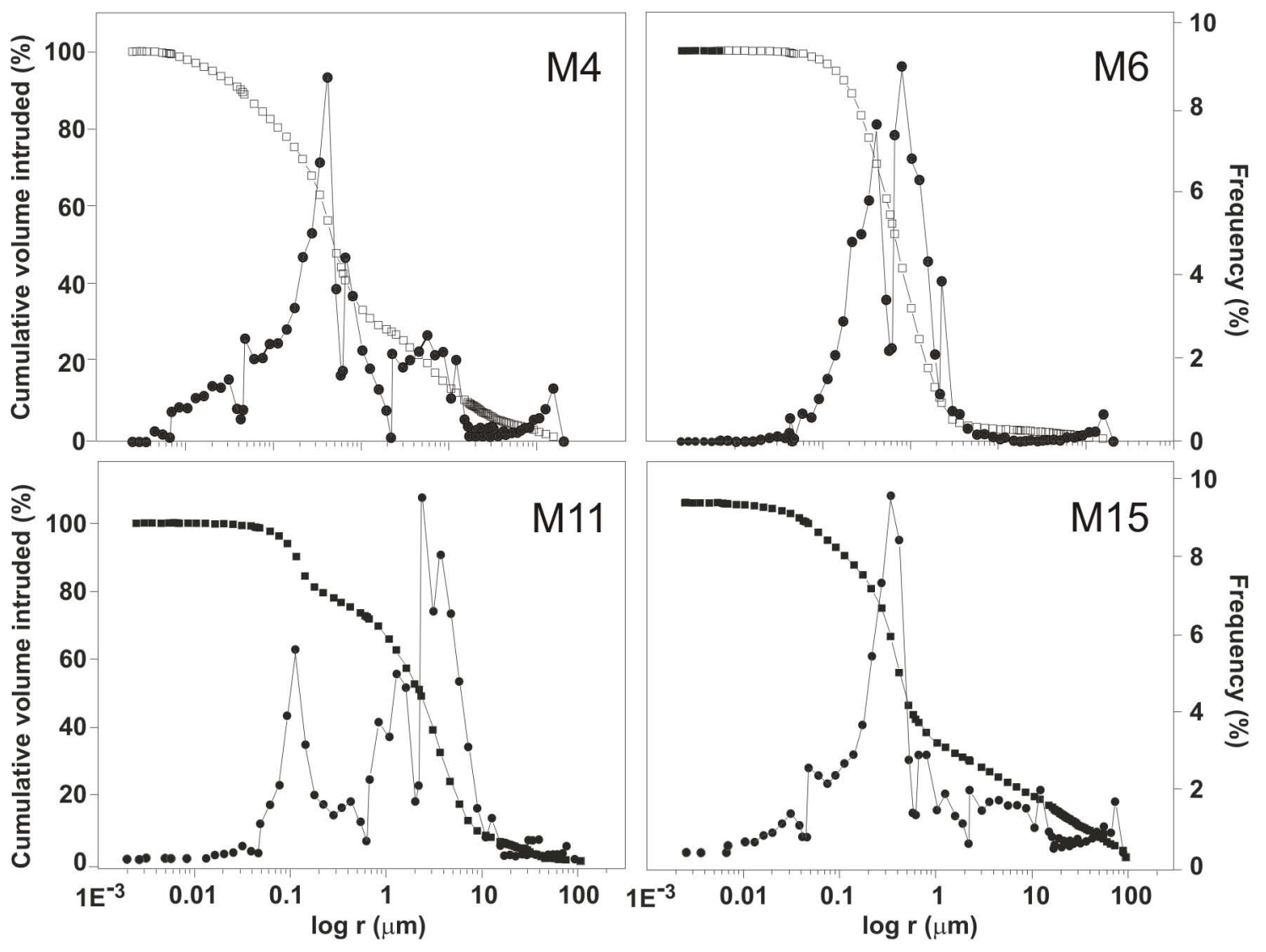




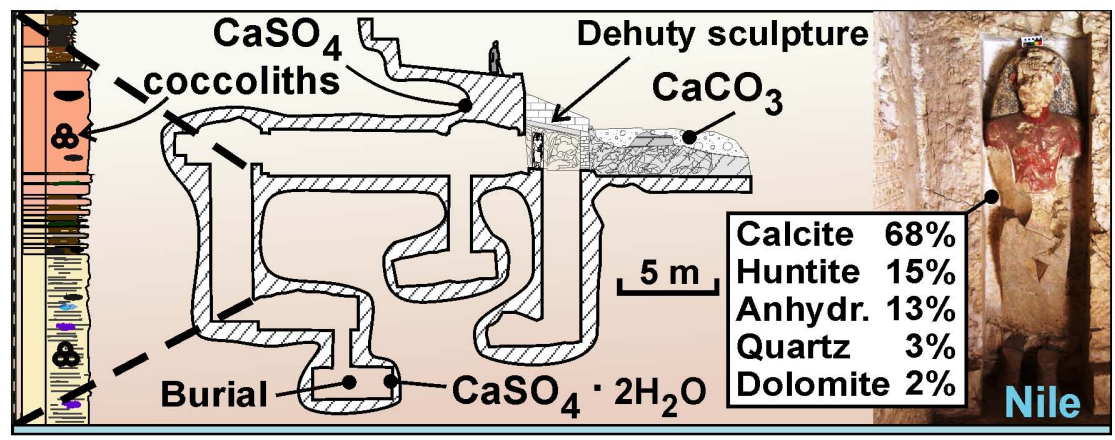

Graphical Abstract (5x13)

The author has requested enhancement of the downloaded file. All in-text references underlined in blue are linked to 